\title{
Fatty acids and chemical composition of peanut (Arachis hypogaea L.)
}

\author{
M. G. Taha ${ }^{1}$, H. Y. M. Yousef ${ }^{1,}{ }^{*}$, S. A. EL-Behery ${ }^{2}$ and H. Mostafa ${ }^{3}$ \\ ${ }^{1}$ Department of Biochemistry, Faculty of Agriculture, Al-Azhar University, Cairo, Egypt \\ 2 National Organization for Drug Control and Research, Giza, Egypt \\ ${ }^{3}$ Food Security Section, Ministry of Defense, Egypt \\ * Correspondence: hanyyousef@azhar.edu.eg (H. Yousef)
}

\begin{abstract}
Because of the shortage of oil and proteins in Egypt, peanut has attracted the interest as good source of oil for human as well as animal consumption. This study was carried out to evaluate the fatty acids and the chemical composition of three varieties of peanut as affected by storage time. The obtained results showed that fat content of the three seed varieties was increased with increasing storage time from 0 time to 9 months then a slight decrease was observed at 12 month stored time. Also, carbohydrates content was increased by increasing the storage time from 0 month to 12 months for all seed varieties. However, protein, Moisture, Ash and fiber percent were decreased with increasing the storage time from 0 month to 12 months. Result indicated that NC peanut variety seeds gave the highest value for fatty acids, physical and chemical composition than Gerogly peanut variety then Balady peanut variety. In conclusion, as decreasing the total saturated fatty acids from 0 to 12 months, the total of unsaturated fatty acids were increased for the three different peanut oils.
\end{abstract}

Keywords: Peanut; Fatty acids; Fatty acids methyl esters (FAME).

\section{INTRODUCTION}

Peanut (Arachis hypogaea L.) is an important oil, food and feed crop of the world. Peanut seeds (Kernels), the most important product of peanut is a rich and a good source of nutrition and provide a several health benefits. The kernels contain $40-55 \%$ oil, $20-35 \%$ protein and $10-20 \%$ carbohydrates. They provide 567 kcal of energy from $100 \mathrm{~g}$ of kernels (Jambunathan, 1991). Fageria et al. (1997) reported that groundnut seeds contain high oil (45\%), $26-28 \%$ protein, $20 \%$ carbohydrates and 5\% fiber. The seeds have high nutritive value for human consumption and for animal feed as well as, the green leaf is also used to hay for livestock (Abdalla et al., 2009). Anyasor et al. (2009) found that the fatty acids composition of different varieties of peanut oils (\%) were as follows: palmitic $10.10-11.85 \%$, stearic $2.67-3.70 \%$ oleic $41.67-44.20 \%$, linoleic $38.50-41.89 \%$, linolenic $0.12-0.15$ arachidic 1.18 $1.76 \%$. The previous literature reported that the oils contain total saturated fatty acids $16.32-29.39 \%$, and the total unsaturated fatty acids from $66.94-83.32 \%$. Ayoola et al., (2010) indicated that the iodine value of peanut oil ranged from 105.7-110.7, saponification value $170-190$ and acids value 1.79-2.52.

Eshun et al. (2013) determined the chemical composition of different varieties of peanut seeds. They reported that moisture 2.13-3.99, protein 17.6222.80, fat content 38.10 to $48.79 \%$, ash 2.4-2.9, carbohydrates $11.50-13.60$ and fiber $12.69-15.55 \%$. The physical and chemical properties were as follow:
Refractive indea 1.460-1.461, colour pale yellow, iodine value 105.1-108.9, and saponification value 144208.9. Anyasor et al. (2009) cleared that peanut seeds contain $4.7 \%$ moisture, $41.2 \%$ oil, $25.8 \%$ fiber, $1.7 \%$ ash, $16.3 \%$ protein and $11.05 \%$ carbohydrate. Therefore, this study was carried out to evaluate the fatty acids and the chemical composition of three varieties of peanut as affected by storage time.

\section{MATERIALS AND METHODS}

The raw peanut seeds of the three varieties were obtained from Wady El-Melouk Farm at Ismaillia during 2017-2018 season.

The raw peanut seeds of the different varieties i.e (Balady, NC and Greogly varieties) were cleared and stored at room temperature for $0,3,6,9$, and 12 months for further analysis.

Proximate Analysis: The proximate analysis of raw peanut in term of moisture fat, protein, fiber, ash and total carbohydrate were determined by NIRA 1650-DFoss at the Central Laboratory, Fac. Agric., A-Azhar Univ.

Oil Extraction: Samples were crushed using an electric grinder and the oils were extracted according to Folch et al. (1957).

The physical and chemical properties of oil samples of the three varieties were determined according to the AOAC. (2010). 
Determination of fatty acid profile: fatty acids were methylated by methylating agent according to Farag et al. (1992). The fatty acid methyl esters (FAME) were dissolved in M-Hexane and chromatographic separation was performed using Thermogas chromatograph instrument equipped with FID using 30m long x 0-32 i.d column. Oven temperature was programmed from $150^{\circ} \mathrm{C}$ for $1 \mathrm{~min}$ then elevated to $230^{\circ} \mathrm{C}$ with the rate of $3^{\circ} \mathrm{C} / \mathrm{min}$.

\section{RESULTS AND DISCUSSIONS}

The results presented in table (1) showed the chemical composition of the three varieties of peanut under this study at the different storage time from 0,3 , 6, 9 and 12 months.

Results indicated that fat content was increased with increasing the storage time from 0 month to 9 months. A slight decrease was observed in 12 months. the NC variety gave the highest values at the different storage time from $0,3,6,9$ and 12 month, the fat contents were 42.98, 43.60, 43.81, 44.50, and $44.30 \%$, respectively.

Also, Carbohydrates content were increased with the storage time. The NC variety gave the lowest values, but Balady variety had the highest value at the different storage time. However, values of moisture, protein, ash and crude fiber were decreased with increasing the storage time from 0 to 12 months (Table, 1).

These results are in harmony with those reported by Jambunatham (1991), Fageria et al. (1997), Anyasor et al. (2009), and Eshun et al. (2013). The physical and chemical properties of peanut seed oils of Balady, NC and Gerogly varieties as affected by storage time are shown in Table 2, 3, and 4 values of refractive index were increased with increasing the storage time at 0,3 , 6 , and 9 months. However, the values were decreased in 12 months. On the other hand, results obtained of acid value, iodine value and saponification value were increased with increasing the storage time from $0,3,6$, 9 and12 month. It could be concluded that the physical and chemical properties were affected by the storage time. these results are in agreement with those obtained by Cifuentes and Cruz (2017), and Elrasheid et al. (2017) who reported that the chemical properties of peanut oil were: saponification value was 168-188 (mg/KOH/g oil) iodine value 86.3-88.11 (g I2/100g oil) and free fatty acids were $0.71-0.80(\mathrm{mg} / \mathrm{KOH} / \mathrm{g}$ oil)

Result presented in Table 5, 6, and 7 showed the effect of storage time $(0,3,6,9$, and 12 month) on fatty acid methyl ester composition of peanut oils of the three varieties under study.

The major detected fatty acids in Balady, NC, and Gerogly peanut oils were palmitic acid C16:0, oleic acid C18:1and linoleic acid C18:2.

Results indicated that values obtained C12:0, C14:0, C15:0, C16:0, C16:1, C18:0, C20:0, C22:0, and C24:0 were decreased with increasing the storage time for all the three oils on the other hand the values of C18:1, $\mathrm{C} 18: 2$, and $\mathrm{C} 18: 3$ were increased with increasing the storage time. The saturated and unsaturated fatty acids were affected by the storage time.

Results indicated that as decreasing the total saturated fatty acids from 0 to 12 month, the total of unsaturated fatty acids were increased for the three different peanut oils.

\section{Conclusion}

It could be concluded that the chemical composition, physical and chemical properties and the fatty acid composition of peanut were affected by the storage time. The NC peanut seed variety had the highest values as compared with Balady and Gerogly peanut seed varieties.

\section{REFERENCES}

Abdalla, A.A., EL-Howeity, M.A., Desoky, A.H., 2009. Response of peanut crop cultivated in newly reclaimed soil to inoculation with plant growth promoting rhizobacteria. Minufiya J.Agric. Res. 34 (6), 2281-2304.

Ayoola, P.B., Adeyeye, A., Onawumi, O.O., 2012. Chemical evaluation of food value of groundnut (Arachis hypogaea L.) seeds Am. J. food Nutr. 2 (3), 55-57.

Anyasor, G.N., Ogunwenmo, K.O., Oyelana, O.A., Ajayi, D., Dangana, J., 2009. Chemical analysis of groundnut (Arachis hypogaea L.) oil. Pak. J. Nutr. 8 (3), 269-272.

A.O.A.C., 2010. Official Mmethods of Analysis. 5th ed., Association of Official Analytical Chemists, Washington DC.

Cifuentes, M.P., Cruz, S.M., 2017. Characterization of seed oil from Arachis hypogaea cultivated in Guatemala for application in lip gloss and shin cream. Int. J. Phytocos. Nat. Ingred. 4, 6.

Elrasheid, E.M.A., Mutoman, A.A.K., Salaman, A.A.A., Maha, A.J.H., Yasir, M.A., 2017. Quality parameters and extraction percentage of the seed-oil of groundnut, sun flower and sesame samples extracted by different solvents. Einstein Int. J. Org. 2 (4), 1-35.

Fageria, N.K., Baligar, V.C., Jones, C., 1997. Growth and Mineral Nutrition of field crop, 2ed ed., Marcel Dakker Inc., NY, pp494.

FAO, 2014. Food and Agriculture Organization of the United Nation. Giews country briefs. http://boostat.fao.org/site/567/default. Aspx\#ancor.

Folch, J., Lees, M., Sloane, G.H., 1957. A simple method for the isolation and purification of total lipids from animal tissues. J. Biol. Chem. 226, 497-509.

Jambunathan, R., 1991. Groundnut quality characteristics. in: Uses of Tropical Grain Legumes. Proceedings of a Consultants Meeting ICRISAT, Patancheru, India. pp. 267-275. 
Table 1. Chemical composition of groundnut seeds (Arachis hypogyae L.) varieties as affected by stored time.

\begin{tabular}{|c|c|c|c|c|c|c|c|}
\hline Stored time (month) & Varieties & Fat & Moist & protein & Ash & Fiber & Total carbon \\
\hline \multirow{3}{*}{$\mathrm{O}$} & Balady & 36.58 & 11.68 & 25.80 & 3.49 & 9.37 & 13.08 \\
\hline & $\mathrm{NC}$ & 42.98 & 9.06 & 26.74 & 3.91 & 6.33 & 10.98 \\
\hline & Gerogly & 40.74 & 9.44 & 25.93 & 3.61 & 8.22 & 12.06 \\
\hline \multirow{3}{*}{3} & Balady & 37.20 & 10.36 & 24.34 & 2.80 & 8.60 & 16.70 \\
\hline & $\mathrm{NC}$ & 43.60 & 8.80 & 26.40 & 2.66 & 6.10 & 12.44 \\
\hline & Gerogly & 41.50 & 8.93 & 24.60 & 2.83 & 7.65 & 14.49 \\
\hline \multirow{3}{*}{6} & Balady & 38.10 & 9.86 & 24.10 & 2.76 & 7.82 & 17.36 \\
\hline & $\mathrm{NC}$ & 43.81 & 8.52 & 26.30 & 2.50 & 5.60 & 13.27 \\
\hline & Gerogly & 41.70 & 8.40 & 24.20 & 2.63 & 6.66 & 16.41 \\
\hline \multirow{3}{*}{9} & Balady & 39.40 & 8.30 & 24.10 & 2.46 & 7.30 & 18.44 \\
\hline & $\mathrm{NC}$ & 44.50 & 7.10 & 25.40 & 2.30 & 5.10 & 15.60 \\
\hline & Gerogly & 42.12 & 7.60 & 23.80 & 2.42 & 6.20 & 17.86 \\
\hline \multirow{3}{*}{12} & Balady & 39.80 & 8.12 & 23.20 & 23.6 & 7.10 & 19.42 \\
\hline & $\mathrm{NC}$ & 44.30 & 7.10 & 24.80 & 2.20 & 5.18 & 16.47 \\
\hline & Gerogly & 42.60 & 7.55 & 22.93 & 2.38 & 6.11 & 18.43 \\
\hline
\end{tabular}

Table 2. Physical and chemical properties of groundnut seed oils (Arachis hypogyae L.) Balady variety as affected by stored time.

\begin{tabular}{ccccc}
\hline Stored time (month) & $\begin{array}{c}\text { Refractive Index } \\
(\mathrm{RI})\end{array}$ & $\begin{array}{c}\text { Acid Value } \\
(\mathrm{AV})\end{array}$ & $\begin{array}{c}\text { Iodine Value } \\
(\mathrm{IV})\end{array}$ & $\begin{array}{c}\text { Saponification Value } \\
(\mathrm{SV})\end{array}$ \\
\hline 0 & 1.4658 & 0.93 & 105.88 & 170.60 \\
3 & 1.4673 & 0.98 & 106.40 & 173.90 \\
6 & 1.4680 & 1.20 & 107.50 & 179.66 \\
9 & 1.4688 & 1.42 & 108.26 & 185.10 \\
12 & 1.4678 & 1.56 & 108.92 & 185.19 \\
\hline
\end{tabular}

Table 3. Physical and chemical properties of groundnut seed oils (Arachis hypogyae L.) NC variety as affected by stored time.

\begin{tabular}{ccccc}
\hline Stored time (month) & $\begin{array}{c}\text { Refractive Index } \\
(\mathrm{RI})\end{array}$ & $\begin{array}{c}\text { Acid Value } \\
(\mathrm{AV})\end{array}$ & $\begin{array}{c}\text { Iodine Value } \\
(\mathrm{Iv})\end{array}$ & $\begin{array}{c}\text { Saponification Value } \\
(\mathrm{Su})\end{array}$ \\
\hline 0 & 1.4670 & 0.88 & 105.20 & 171.30 \\
3 & 1.4676 & 0.96 & 106.26 & 178.40 \\
6 & 1.4682 & 1.20 & 107.30 & 182.20 \\
9 & 1.4690 & 1.38 & 107.22 & 183.40 \\
12 & 1.4684 & 1.49 & 107.40 & 184.12 \\
\hline
\end{tabular}

Table 4. Physical and chemical properties of groundnut seed oils (Arachis hypogyae L.) Gerogly variety as affected by stored time.

\begin{tabular}{ccccc}
\hline Stored time (month) & $\begin{array}{c}\text { Refractive Index } \\
(\mathrm{RI})\end{array}$ & $\begin{array}{c}\text { Acid Value } \\
(\mathrm{AV})\end{array}$ & $\begin{array}{c}\text { Iodine Value } \\
(\mathrm{Iv})\end{array}$ & $\begin{array}{c}\text { Saponification Value } \\
(\mathrm{Su})\end{array}$ \\
\hline 0 & 1.4681 & 0.94 & 106.30 & 172.94 \\
3 & 1.4686 & 0.99 & 107.22 & 182.60 \\
6 & 1.4690 & 1.22 & 108.60 & 185.40 \\
9 & 1.4692 & 1.46 & 108.94 & 186.10 \\
12 & 1.4688 & 1.58 & 108.90 & 187.30 \\
\hline
\end{tabular}


Table 5. Fatty acid methyl ester (FAME) composition of groundnut seed oil (Arachis hypogyae L.) Balady variety as affected by stored time.

\begin{tabular}{llllll}
\hline Fatty Acid Methyl Ester. & \multicolumn{5}{c}{ Stored time (month) } \\
\cline { 2 - 6 } & $\mathbf{0}$ & $\mathbf{3}$ & $\mathbf{6}$ & $\mathbf{9}$ & $\mathbf{1 2}$ \\
\hline Lauric C12-0 & 0.16 & 0.12 & 0.10 & 0.08 & 0.06 \\
Myristic C14-0 & 0.69 & 0.56 & 0.48 & 0.42 & 0.40 \\
Pentadecanoic C15-0 & 0.60 & 0.50 & 0.42 & 10.32 & 0.36 \\
Palmitic C16-0 & 11.60 & 10.66 & 10.57 & 0.12 & 10.20 \\
Palmitoleic C16-1 & 0.25 & 0.20 & 0.16 & 2.30 & 0.10 \\
Stearic C18-0 & 2.70 & 2.60 & 2.50 & 41.91 & 4.25 \\
Oleic C18-1 & 40.80 & 41.10 & 41.33 & 39.82 & 40.12 \\
Linoleic C18-2 & 36.70 & 38.30 & 39.60 & 0.76 & 0.80 \\
Linolenic C18-3 & 0.63 & 0.66 & 0.67 & 2.10 & 2.10 \\
Arachidic C20-0 & 2.95 & 2.60 & 2.58 & 1.30 & 1.25 \\
Behenic C22-0 & 1.75 & 1.60 & 1.53 & 0.82 & 0.70 \\
Lignoceric C24-0 & 1.17 & 1.10 & 1.06 & 17.7 & 18.22 \\
Total SFA & 21.62 & 19.74 & 19.24 & 82.61 & 81.78 \\
Total USFA & 78.38 & 80.26 & 81.76 & & \\
\hline
\end{tabular}

Table 6. Fatty acid methyl ester (FAME) composition of groundnut seed oil (Arachis hypogyae L.) NC variety as affected by stored time.

\begin{tabular}{lccccc}
\hline Fatty acid methyl ester (FAME) & \multicolumn{3}{c}{ Stored time (month) } \\
\cline { 2 - 6 } & 0 & 3 & 6 & 9 & 12 \\
\hline Lauric C12-0 & 0.28 & 0.22 & 0.18 & 0.12 & 0.10 \\
Myristic C14-0 & 0.80 & 0.73 & 0.60 & 0.54 & 0.50 \\
Pentadecanoic C15-0 & 0.76 & 0.70 & 0.66 & 0.42 & 0.42 \\
Palmitic C16-0 & 12.38 & 12.10 & 11.30 & 10.20 & 9.93 \\
Palmitoleic C16-1 & 0.32 & 0.27 & 0.24 & 0.16 & 0.15 \\
Stearic C18-0 & 2.94 & 2.80 & 2.64 & 2.48 & 2.40 \\
Oleic C18-1 & 42.20 & 42.60 & 43.10 & 43.80 & 43.94 \\
Linoleic C18-2 & 33.10 & 33.86 & 35.02 & 36.49 & 36.55 \\
Linolenic C18-3 & 0.74 & 0.80 & 0.86 & 0.92 & 0.94 \\
Arachidic C20-0 & 3.20 & 2.93 & 2.64 & 2.44 & 2.20 \\
Behenic C22-0 & 1.88 & 1.73 & 1.62 & 1.40 & 1.31 \\
Lignoceric C24-0 & 1.40 & 1.26 & 1.14 & 1.03 & 1.01 \\
Total SFA & 23.64 & 22.74 & 20.78 & 18.63 & 17.87 \\
Total USFA & 76.36 & 77.53 & 79.22 & 81.37 & 82.13 \\
\hline
\end{tabular}

Table 7. Fatty acid methyl ester (FAME) composition of groundnut seed oil (Arachis hypogyae L.) Gerogly variety as affected by stored time.

\begin{tabular}{|c|c|c|c|c|c|}
\hline \multirow{2}{*}{ Fatty Acid Methyl Ester (FAME) } & \multicolumn{5}{|c|}{ Stored time (month) } \\
\hline & 0 & 3 & 6 & 9 & 12 \\
\hline Lauric C12-0 & 0.24 & 0.20 & 0.16 & 0.10 & 0.11 \\
\hline Myristic C14-0 & 0.70 & 0.64 & 0.56 & 0.48 & 0.43 \\
\hline Pentadecanoic C15-0 & 0.80 & 0.66 & 0.54 & 0.40 & 0.36 \\
\hline Palmitic C16-0 & 11.60 & 11.30 & 11.20 & 10.10 & 10.05 \\
\hline Palmitoleic C16-1 & 0.30 & 0.22 & 0.20 & 0.14 & 0.12 \\
\hline Stearic C18-0 & 2.82 & 2.63 & 2.50 & 2.40 & 2.32 \\
\hline Oleic C18-1 & 41.60 & 41.80 & 42.13 & 42.44 & 42.60 \\
\hline Linoleic C18-2 & 35.48 & 36.16 & 36.65 & 38.32 & 38.80 \\
\hline Linolenic C18-3 & 0.56 & 0.74 & 0.80 & 0.88 & 0.92 \\
\hline Arachidic C20-0 & 2.90 & 2.82 & 2.60 & 2.36 & 2.29 \\
\hline Behenic C22-0 & 1.70 & 1.63 & 1.54 & 1.34 & 1.30 \\
\hline Lignoceric C24-0 & 1.30 & 1.20 & 1.12 & 1.01 & 1.10 \\
\hline Total SFA & 22.06 & 21.08 & 20.22 & 18.19 & 17.87 \\
\hline Total USFA & 77.94 & 78.92 & 79.78 & 81.78 & 82.13 \\
\hline
\end{tabular}




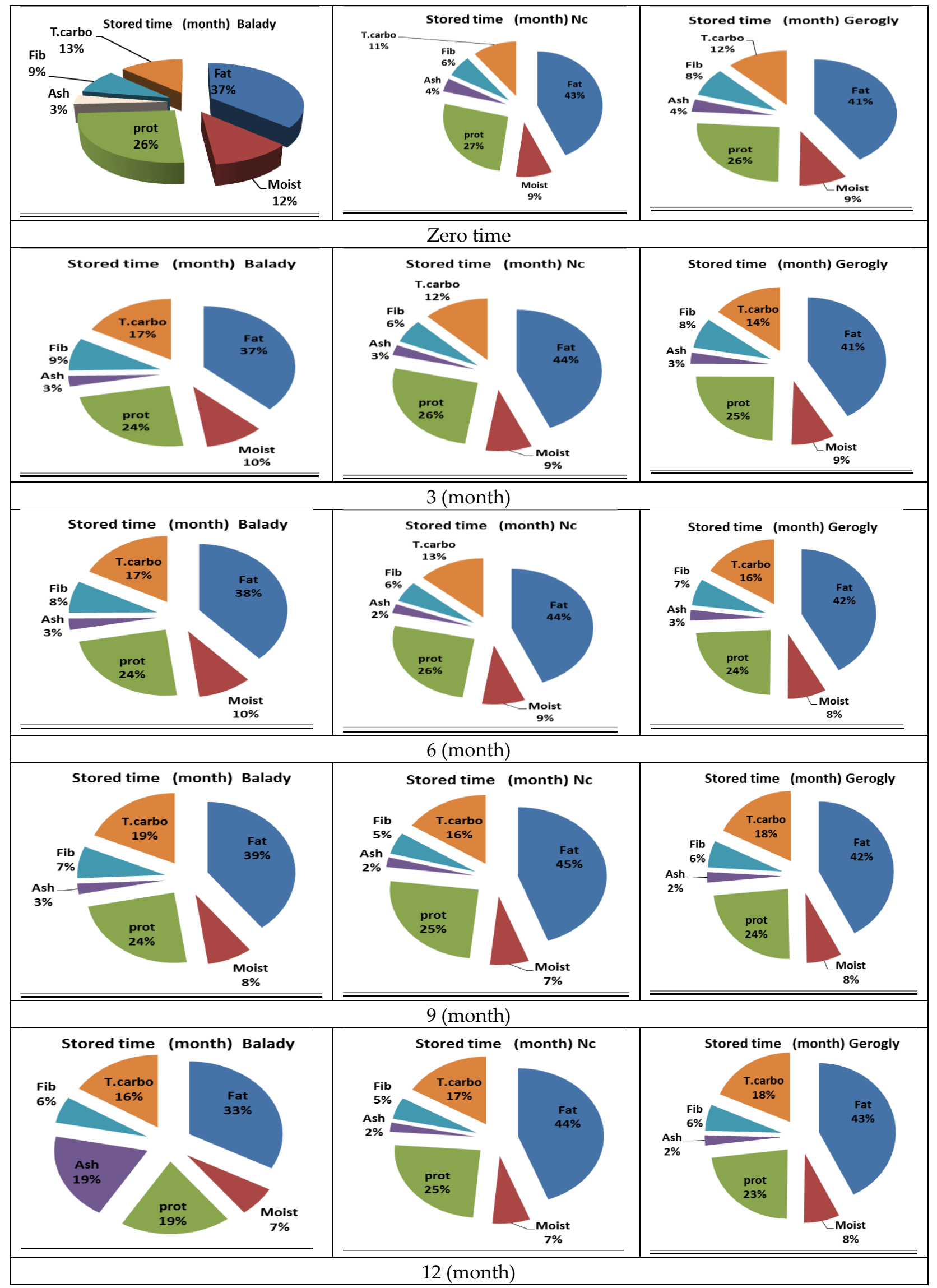

Fig. 1. Chemical composition of groundnut seeds (Arachis hypogyae L.) varieties as affected by stored time. 


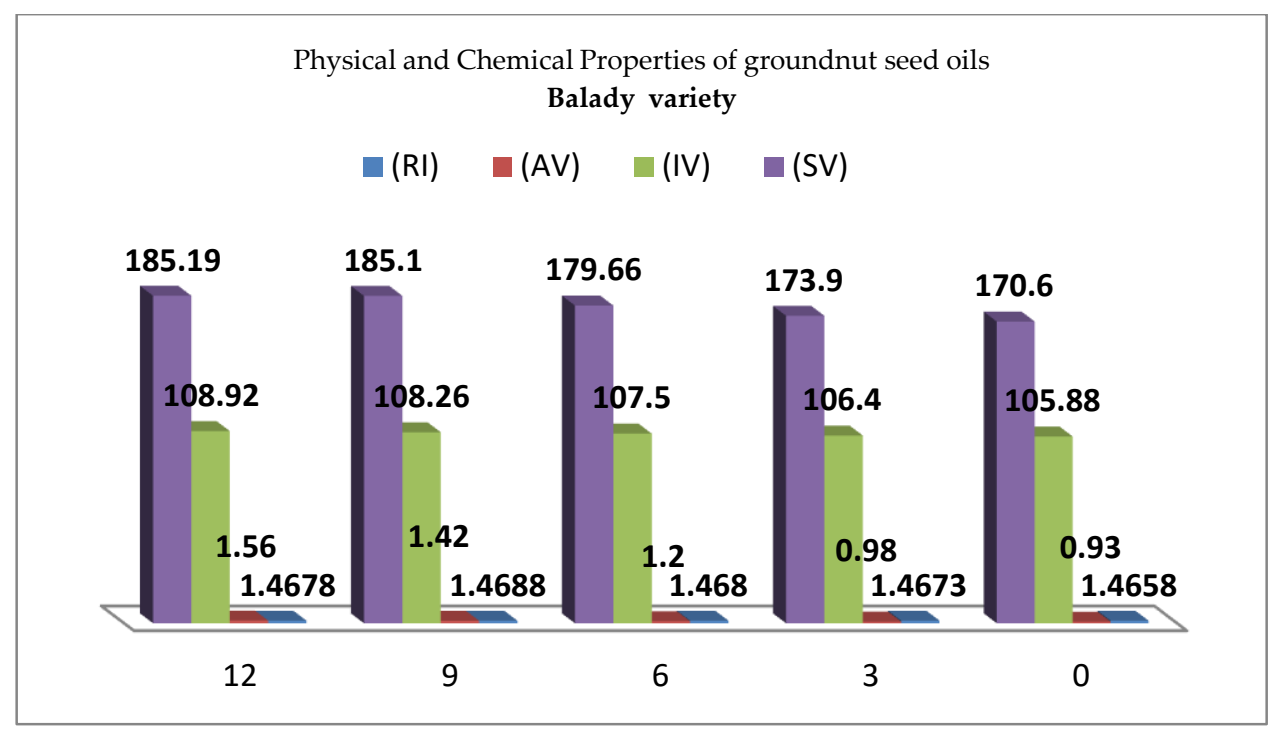

Fig. 2. Physical and chemical properties of groundnut seed oils (Arachis hypogyae L.) Balady variety as affected by stored time.

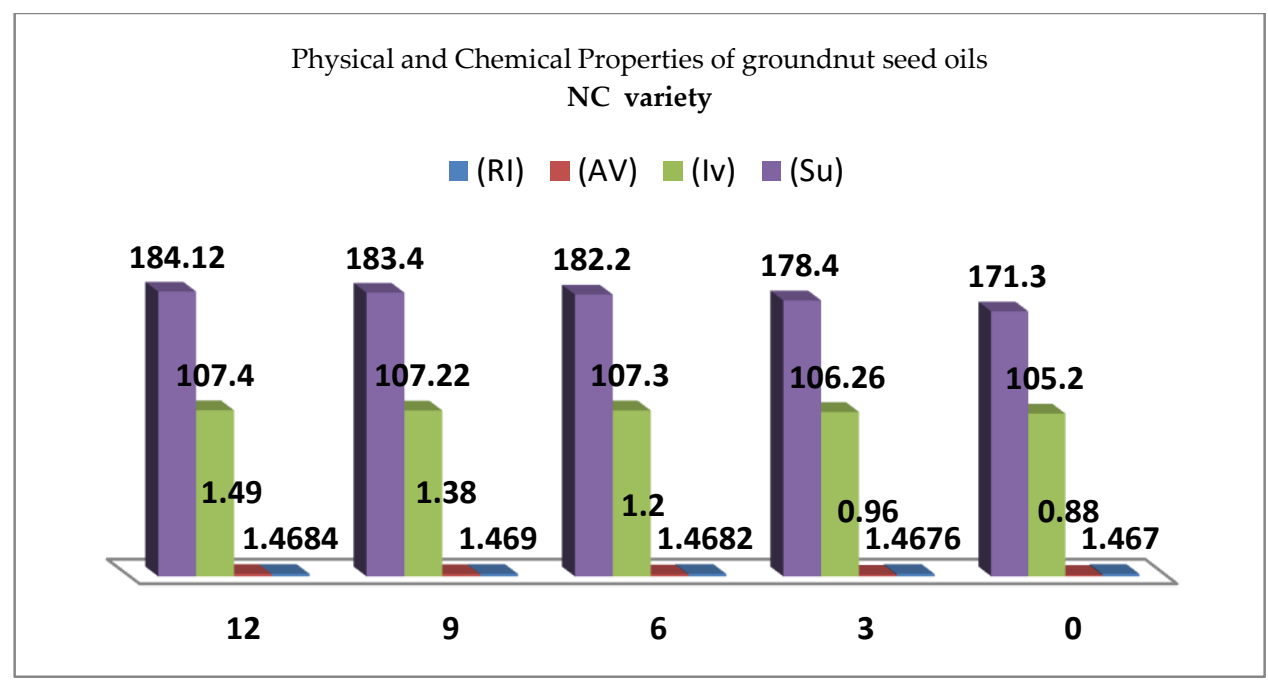

Fig. 3. Physical and chemical properties of groundnut seed oils (Arachis hypogyae L.) NC variety as affected by stored time.

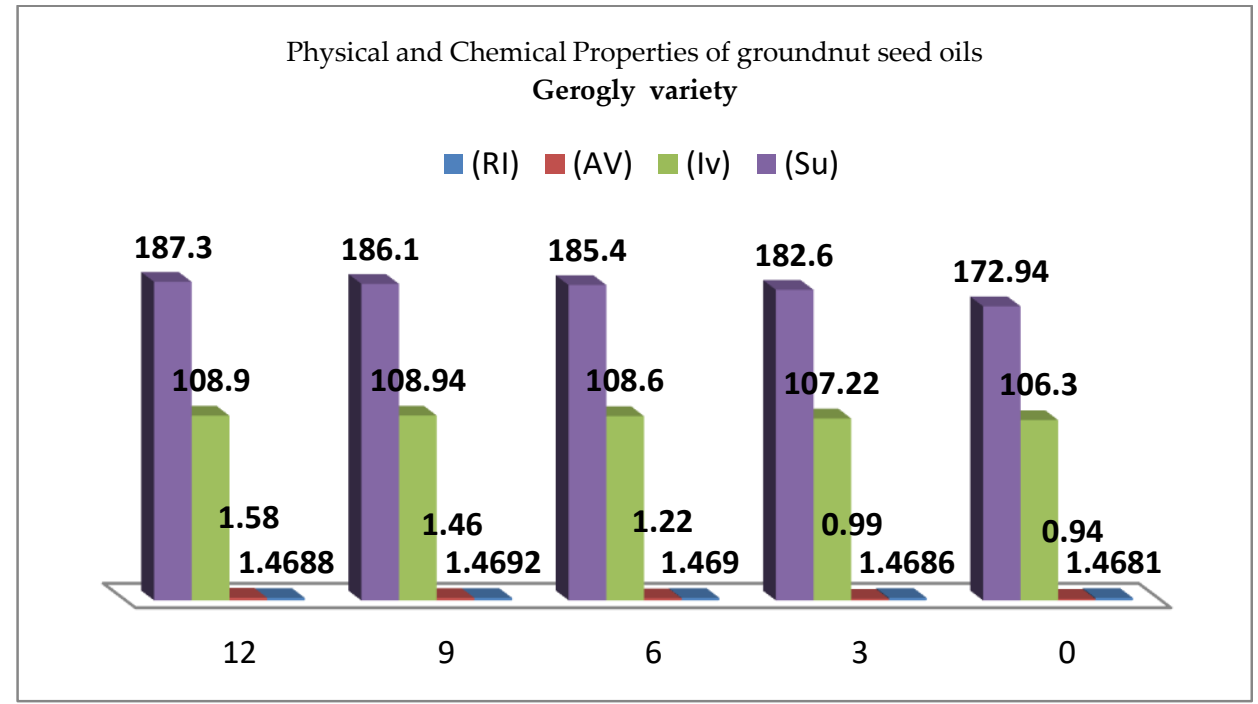

Fig. 4. Physical and chemical properties of groundnut seed oils (Arachis hypogyae L.) Gerogly variety as affected by stored time. 


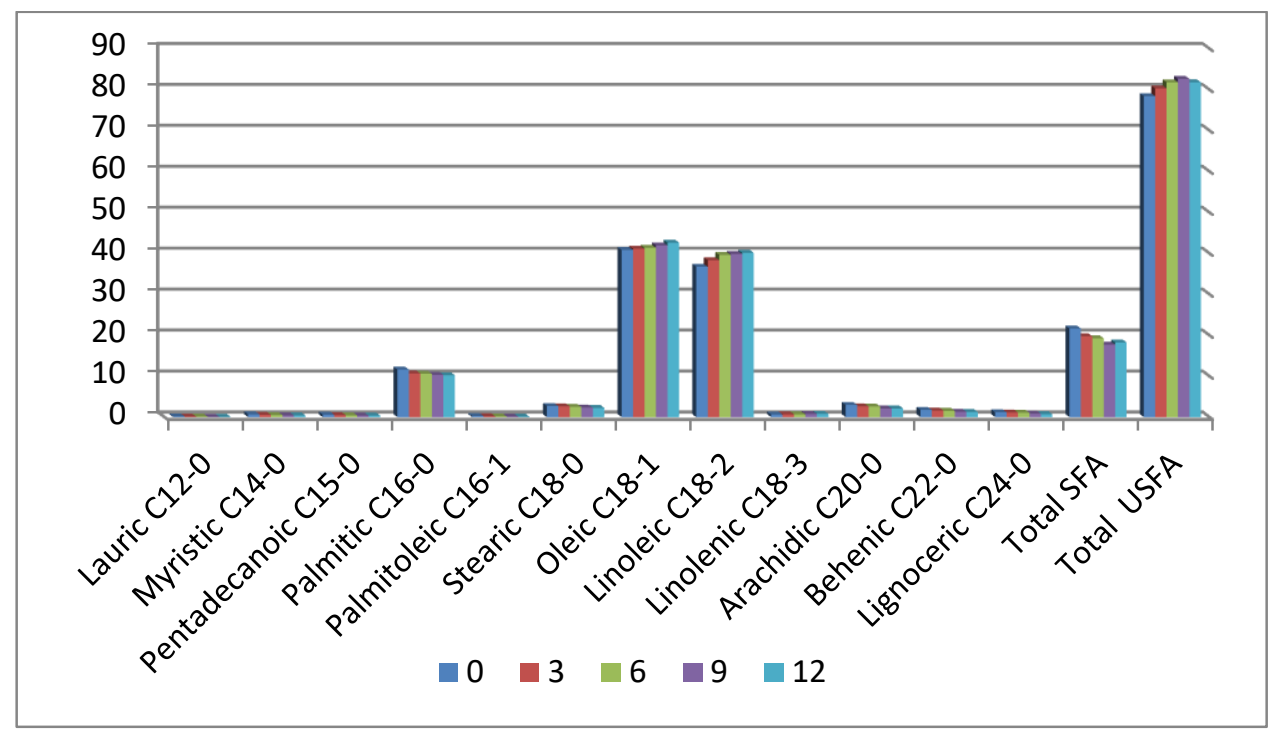

Fig. 5. Fatty acid methyl ester (FAME) composition of groundnut seed oil (Arachis hypogyae L.) Balady variety as affected by stored time.

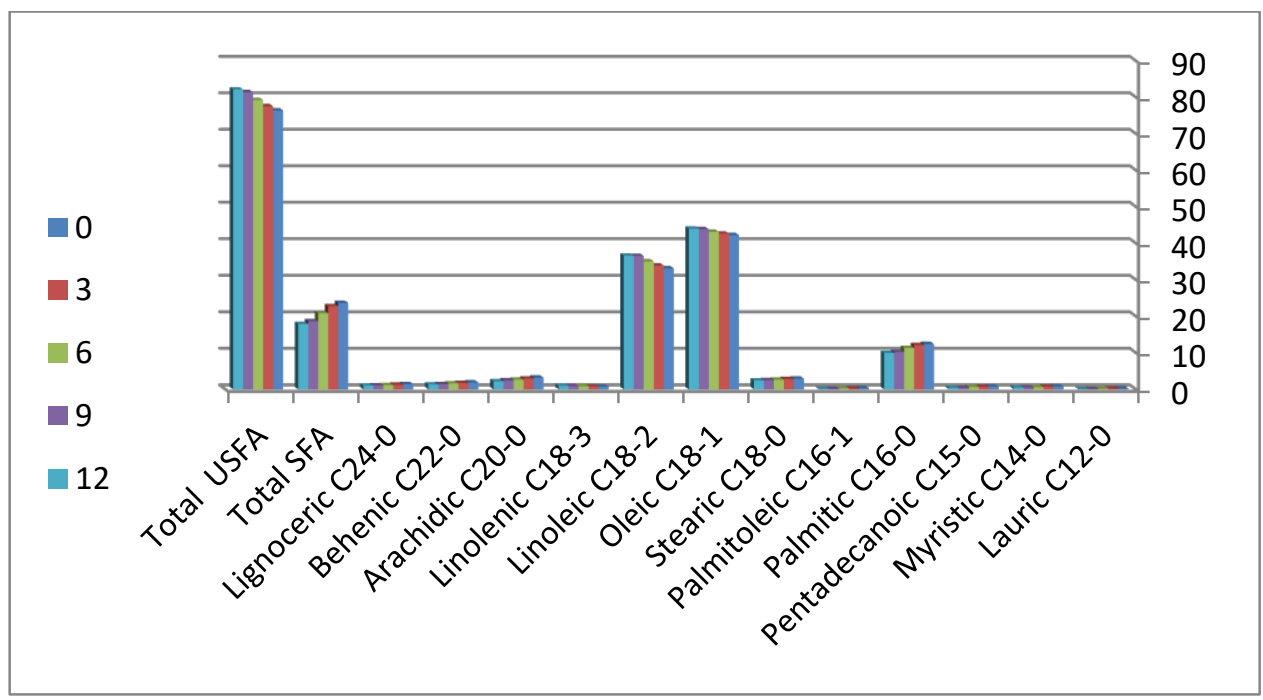

Fig. 6. Fatty acid methyl ester(FAME) composition of groundnut seed oil (Arachis hypogyae L.) NC variety as affected by stored time. 


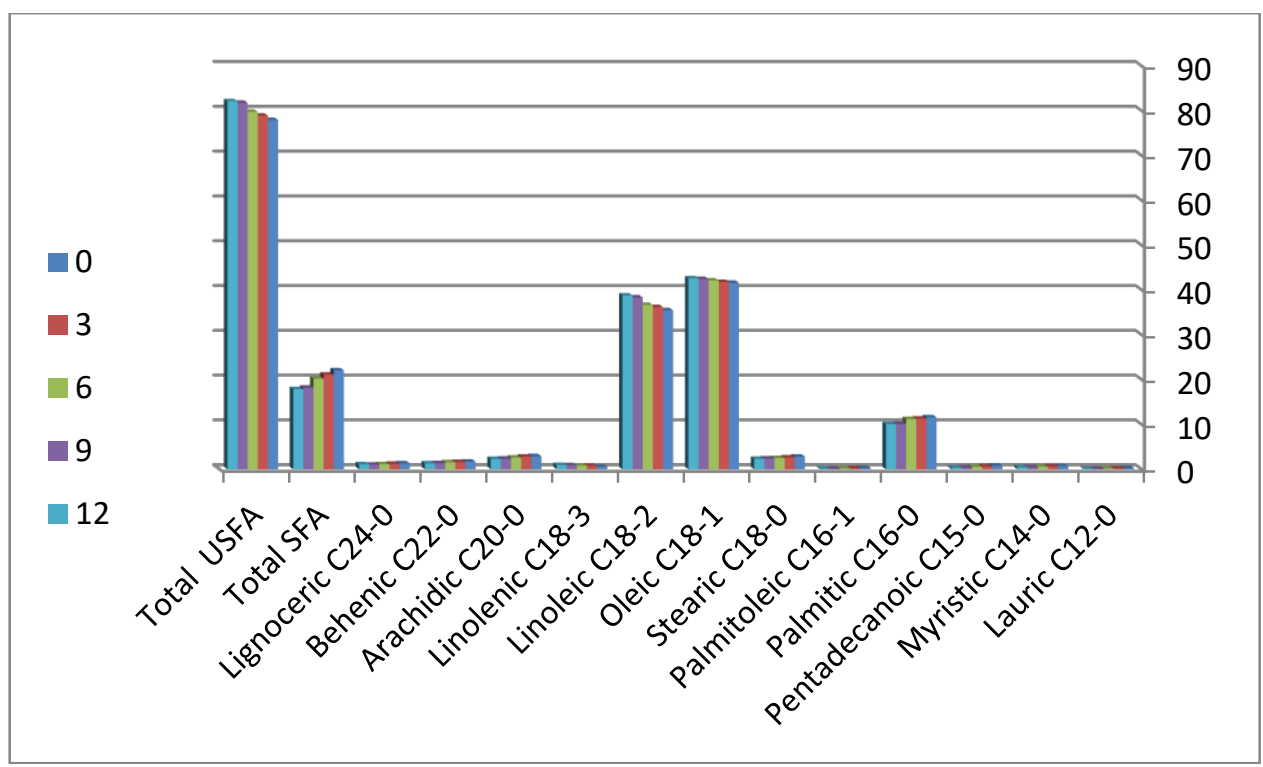

Fig. 7. Fatty acid methyl ester (FAME) composition of groundnut seed oil (Arachis hypogyae L.) Gerogly variety as affected by stored time. 


\section{الاحاض الدهنية والمكونات الكيميائية للفول السوداني}

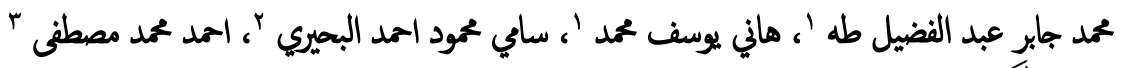

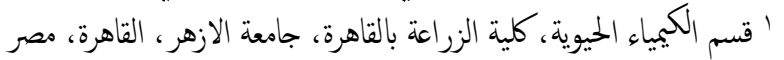

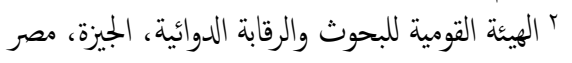

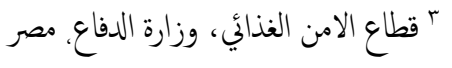

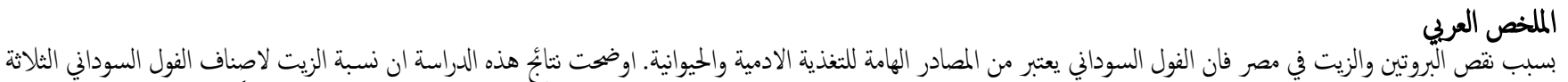

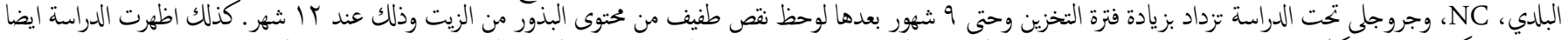

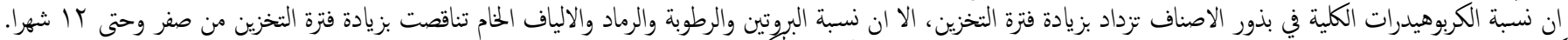

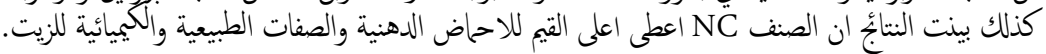

